\title{
Non-fatal Bihemispheric Penetrating Brain Injury from a Crossbow Arrow with Good Clinical Outcome: Case Report
}

\section{Lesão cerebral penetrante bi-hemisférica não fatal por flecha de besta com bom desfecho clínico: Relato de caso}

\author{
José Gonçalo de Oliveira Machado Saraiva Januário ${ }^{10}$ Gonçalo Abreu Mesquita Borges de Almeida ${ }^{2}$
} Carlos José Rios Godinho Calado ${ }^{1}$ Joaquim António Toscano Ferreira Monteiro ${ }^{1}$

${ }^{1}$ Department of Neurosurgery, Hospital de São José, Lisboa, Portugal
${ }^{2}$ Department of Neuroradiology, Hospital de São José, Lisboa, Portugal

Arq Bras Neurocir 2021;40(2):e179-e182.
Address for correspondence José Januário, MD, Departmento de Neurocirurgia, Hospital de São José, Rua José António Serrano, Lisboa, 1150-199, Portugal (e-mail: jg.machado@hotmail.com).

\begin{abstract}
Keywords

- Craniocerebral Trauma

- penetrating brain injury

- foreign bodies

- posttraumatic subarachnoid hemorrhage
\end{abstract}

\section{Resumo}

Crossbow injuries to the head have seldom been reported in the literature, and they represent a unique type of penetrating brain injury (PBI) in which a low-velocity arrow results in an intracranial fragment larger than most high-velocity projectiles, usually with a lethal outcome. We present the case of a 34-year-old man who attempted suicide with a self-inflicted cranial injury from a crossbow arrow, with a right parietal point of entry and a palpable subcutaneous tip in the left parietal region. The emergency team reported a Glasgow coma scale (GCS) score of 15, and the patient was brought sedated and intubated. Computed tomography (CT) imaging scans showed that the arrow crossed both parietal lobes, with mild subarachnoid hemorrhage and small cerebral contusions adjacent to its intracranial path. Careful retrograde removal of the penetrating arrow was performed in the $\mathrm{CT}$ suite, followed by an immediate $\mathrm{CT}$ scan, which excluded procedure-related complications. The patient woke up easily and was discharged 3 days later with mild left hand apraxia and no other neurologic deficits. To the best of our knowledge, there are no similar case reports describing both good clinical outcome and rapid discharge after a bihemispheric PBI. Individualizing the management of each patient is therefore crucial to achieve the best possible outcome as PBI cases still represent a major challenge to practicing neurosurgeons worldwide.

As lesões cranianas causadas por bestas raramente foram relatadas na literatura, e representam um tipo único de lesão cerebral penetrante (LCP), na qual uma flecha de baixa velocidade resulta em um fragmento intracraniano maior do que a maioria dos projéteis de alta velocidade, geralmente com um resultado letal. Apresentamos o caso de um homem de 34 anos que tentou suicídio com lesão craniana autoinfligida por uma received

May 11,2020

accepted

September 4, 2020

published online

February 15, 2021
DOI https://doi.org/ 10.1055/s-0040-1719008. ISSN 0103-5355.

\footnotetext{
(c) 2021. Sociedade Brasileira de Neurocirurgia. All rights reserved. This is an open access article published by Thieme under the terms of the Creative Commons Attribution-NonDerivative-NonCommercial-License, permitting copying and reproduction so long as the original work is given appropriate credit. Contents may not be used for commercial purposes, or adapted, remixed, transformed or built upon. (https://creativecommons.org/ licenses/by-nc-nd/4.0/)

Thieme Revinter Publicações Ltda., Rua do Matoso 170, Rio de Janeiro, RJ, CEP 20270-135, Brazil
} 


\author{
Palavras-chave \\ - trauma \\ craniocerebral \\ - lesão encefálica \\ penetrante \\ - corpos estranhos \\ - hemorragia \\ subaracnoideia pós- \\ traumática
}

flecha de besta, com um ponto de entrada parietal direito e uma ponta subcutânea palpável na região parietal esquerda. A equipe de emergência relatou uma pontuação na escala de coma de Glasgow (ECG) de 15, e o paciente foi levado sedado e intubado. A tomografia computorizada (TC) mostrou que a seta cruzava ambos os lobos parietais, com ligeira hemorragia subaracnoideia e pequenas contusões cerebrais adjacentes ao seu trajeto intracraniano. Foi realizada remoção retrógrada cuidadosa da flecha penetrante na sala de TC, seguida de TC imediata, que excluiu complicações relacionadas ao procedimento. $\mathrm{O}$ paciente acordou facilmente e recebeu alta 3 dias depois com apraxia leve da mão esquerda e sem outros défices neurológicos. Do que sabemos, não há relatos de casos semelhantes que descrevam bom resultado clínico e alta rápida após LCP bihemisférica. Individualizar o tratamento de cada paciente é, portanto, crucial para alcançar o melhor resultado possível, pois os casos de LCP ainda representam um grande desafio para neurocirurgiões praticantes em todo o mundo.

\section{Introduction}

Penetrating brain injury (PBI) refers to a type of traumatic brain injury in which a foreign object penetrates the skull and injures the brain. It is less common than blunt head trauma, accounting for only $10 \%$ of all head injuries, although its consequences are generally worse., ${ }^{1,2}$

Most cases of PBI are caused by gunshot bullets. Knives, arrows, spears, rocks, screwdrivers, chopsticks and other sharp objects have also been reported. ${ }^{1}$

Crossbow injuries represent a unique type of PBI in which a low-velocity foreign body (arrow) results in an intracranial fragment larger than high-velocity gunshot bullets. ${ }^{3}$ There are very few reports in the literature regarding this type of PBI, each one requiring singular assessment and management.

The present report describes the rare case of a non-fatal self-inflicted head injury from a crossbow arrow which penetrated both parietal lobes, resulting in mild neurologic impairment after the successful removal of the arrow.

\section{Case Report}

A 34 year-old Portuguese man with a history of major depression attempted suicide with a self-inflicted head injury from a crossbow arrow.

The emergency team was called and reported the presence of a PBI from a crossbow arrow with a right parietal point of entry. The tip of the arrow was palpable right under the skin of the left parietal region, with no exit wound. A Glasgow coma scale (GCS) score of 15 was reported, and the patient only complained of right upper limb paresthesia, with no evidence of hemorrhage on the spot. Sedation, endotracheal intubation and connection to a ventilatory prosthesis were performed, and the patient was transferred to the emergency department of our hospital.

In the emergency department, continuous infusion of propofol was started, and a full laboratory work-up was performed, showing mild normocytic anemia (hemoglobin $12,6 \mathrm{mg} / \mathrm{dl}$ ), neutrophilic leukocytosis $\left(12 \times 10^{9} / \mathrm{L}\right.$ leukocytes with $89 \%$ of neutrophils) and elevated C-reactive protein $(3,2 \mathrm{mg} / \mathrm{dl})$, with no sign of drug intoxication or coagulation-related disorders. The chest radiography and the electrocardiogram were also normal. The patient was taken to the computed tomography (CT) suite, ( - Fig. 1a) and underwent a CT imaging scan of the brain, which documented sulcal subarachnoid hemorrhage (SAH), mainly on the left parieto-occipital region, as well as cerebral contusions along the intracranial path of the crossbow arrow ( $\mathbf{F i g . ~ 1 b ) . ~}$ Bone-window imaging assessment confirmed the aforementioned path of the arrow ( $\mathbf{F}$ Fig. 1c), and a three-dimensional (3D) reconstruction of the skull surprisingly showed three calvarial defects in the right parietal region confirming three different suicide attempts, of which only one represented a PBI (-Fig. 1d).

Given the long intracranial course of the object, involving multiple brain compartments, we preferred to remove the penetrating arrow in the CT suite, as it would be possible to immediately locate any possible source of hemorrhage during the procedure. The arrow was therefore removed manually along the respective penetrating route. A new CT scan of the brain showed no evidence of procedure-related complications.

The patient was subsequently transferred to the intensive care unit. After propofol withdrawal and extubation, the patient woke up easily, with mild left-hand apraxia and no other neurologic deficits. Antibiotic prophylaxis with intravenous amoxicillin-clavulanate was introduced due to the increased risk of infection. A control CT scan was performed the day following the removal of the crossbow arrow, demonstrating the expected decrease in attenuation of the aforementioned hemorrhagic lesions, with slight increase in the area of the surrounding edema (-Fig. 2a).

Finally, the patient was transferred to the Department of Neurosurgery. After a final clinical assessment, he was discharged and remained under follow-up appointments. A control CT scan performed three weeks later showed complete resolution of the sulcal SAH and cerebral contusions (- Fig. 2b).

\section{Discussion}

Crossbow injuries to the head have rarely been reported in the literature, and most of them had a fatal outcome and happened in developing countries as a result of robberies, 


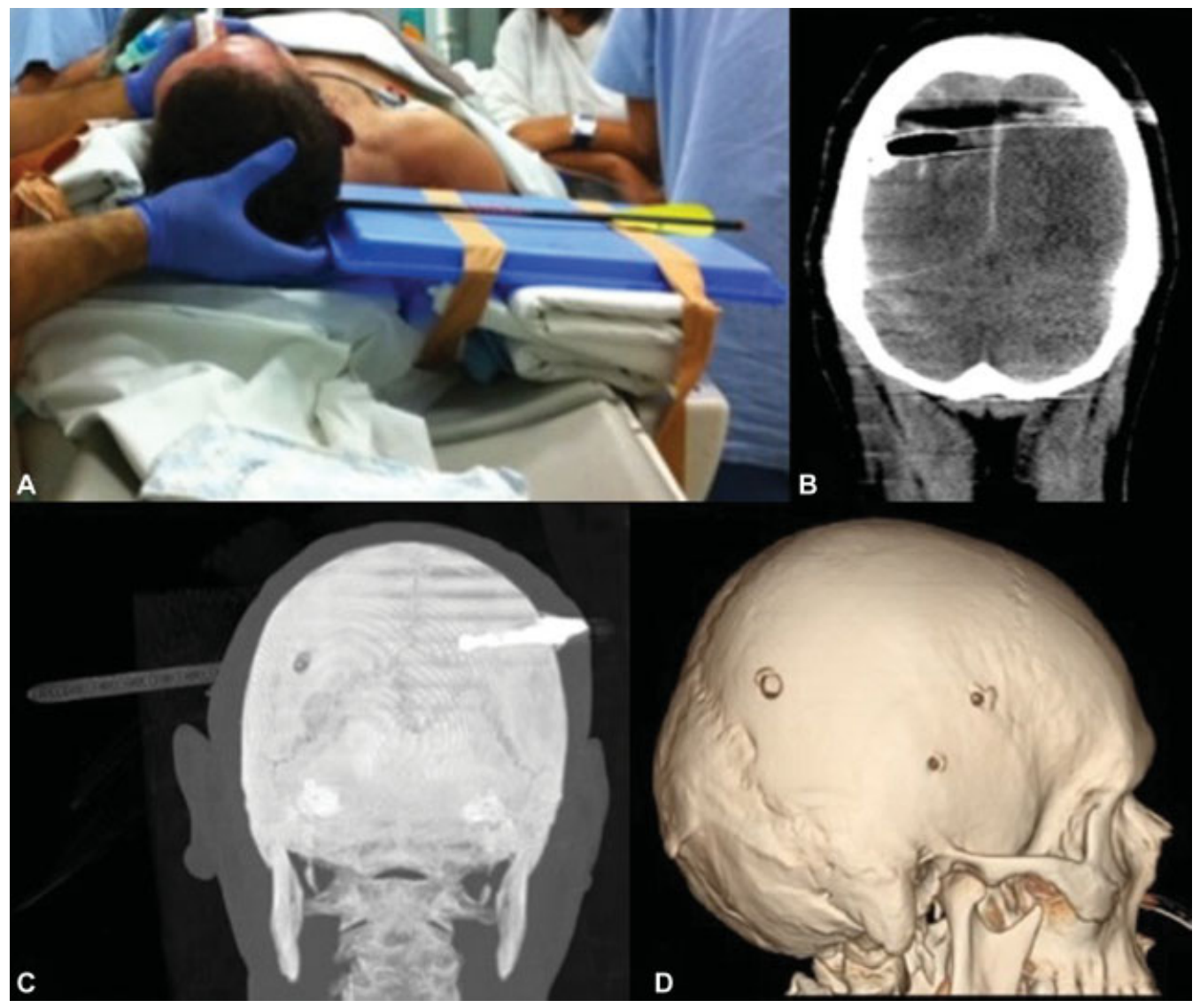

Fig. 1 (A) Photograph of the patient in the CT suite with the crossbow arrow entering the right parietal calvaria. (B) The CT imaging scan showing mild sulcal SAH and cerebral contusions along the intracranial path of the arrow, with multiple artifacts from metallic hardware. (C) Bone window CT scan demonstrating a subcutaneous arrow tip in the left parietal region. (D) 3D reconstruction of the skull showing three calvarial defects in the right parietal region, confirming a total of three suicide attempts.

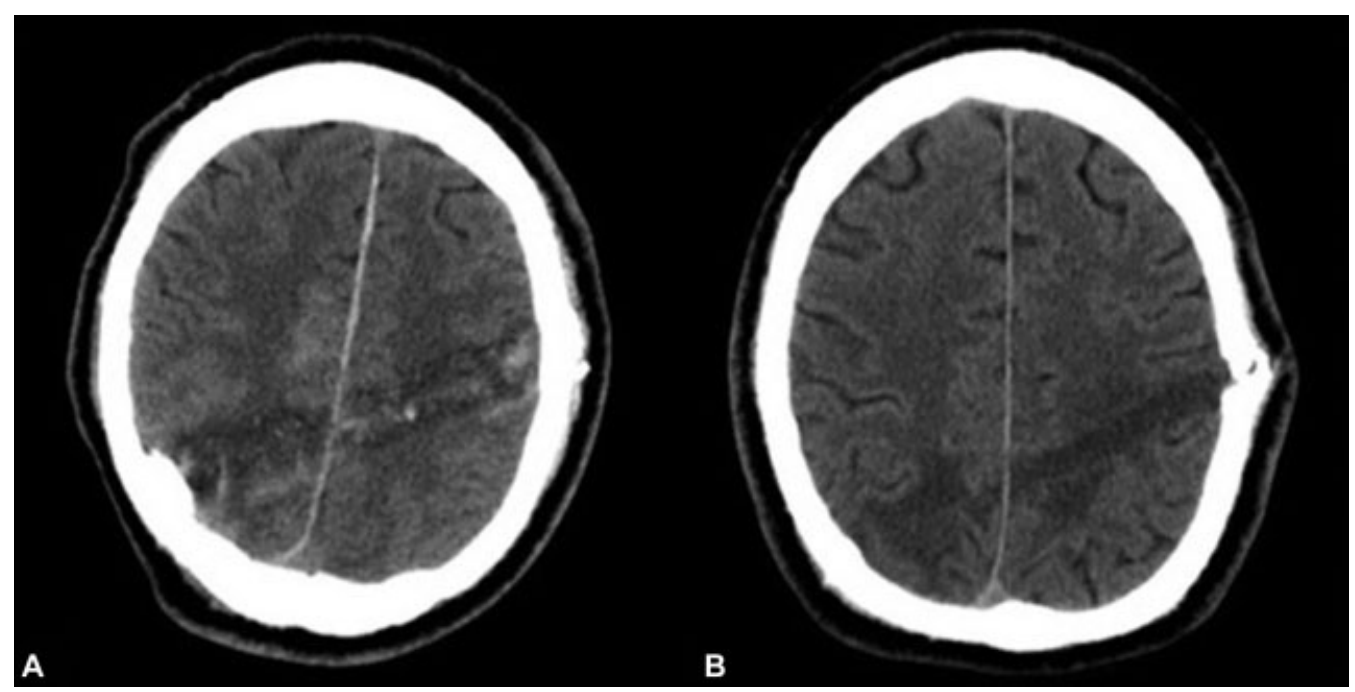

Fig. 2 (A) Control CT scan performed the day following the removal of the crossbow arrow, demonstrating the expected decrease in attenuation of the sulcal SAH and cerebral contusions, with a slight increase in the area of the surrounding edema. (B) Control CT scan performed 3 weeks later, showing complete resolution of the aforementioned hemorrhagic lesions.

communal clashes, disputes between farmers and cattle herdsmen, and cattle theft. ${ }^{4}$

Despite having a relative low-velocity (as fast as $58 \mathrm{~m} / \mathrm{sec}$ ) compared with firearm projectiles, the sharpness and propulsion force of the crossbow may be enough to enable penetrating injuries of the skull at short range. ${ }^{5}$ In these cases, the conse- quences of the PBI depend on multiple factors, including the size of the penetrating object, the energy and speed of entry, the intracranial path, changes in intracranial pressure, and associated injuries. ${ }^{1,6}$ Since the tip of the arrow and its shaft have the same diameter, the injury is generally limited to the tissues directly crossed by the blade, and may be non-fatal. ${ }^{1,5}$ 
In the case herein reported, the crossbow arrow penetrated the right parietal calvaria and crossed both parietal lobes, with a palpable subcutaneous tip in the left parietal region. Given the absence of neurologic deficits at the initial assessment, the intracranial path of the arrow and the report of mild sulcal SAH and small cerebral contusions adjacent to its shaft on CT imaging, we regarded the possibility of major vessel damage as less likely to have occurred. Nonetheless, the rate of vascular complications after TBIs can range from $5 \%$ to $40 \%$, and it mostly corresponds to traumatic aneurysms, arteriovenous fistulas, SAH, vasospasm and venous thrombosis. Special attention must be payed to traumatic aneurysms, which may present in a delayed fashion (typically two to three weeks after the injury). Therefore, followup CT-angiography and digital subtraction angiography should be performed at least four weeks after the incident. ${ }^{7}$

The management strategy of the intracranial foreign body was another major challenge. First, most case reports of cranial crossbow and other low-velocity injuries describe removal in the operating room, enabling hemostasis, debridement of necrotic tissues, and closure. ${ }^{3}$ Given the long intracranial trajectory of the arrow, and since vascular injury is sometimes only revealed with the removal of the foreign body, we decided to remove retrogradely the arrow in the CT suite, as it would enable the prompt recognition of a possible source of hemorrhage. In addition, the patient presented with a small skin injury with healthy edges, with no need for wound debridement. Kulwin et al. ${ }^{3}$ suggest that the removal of arrows and similar low-velocity large penetrating projectiles should occur in a radiologic setting due to increased patient safety and optimized healthcare costs. Nevertheless, the operating room was put on notice for possible emergency surgery in case of severe procedure-related hemorrhage. Secondly, most case reports describe anterograde removal of the penetrating arrow to avoid further damage from the razorsharp blades. ${ }^{1}$ Considering that no exit wound was found, we performed a careful retrograde removal followed by immediate CT imaging scans to exclude procedure-related damages.

Infectious complications of arrow-induced cranial injuries are not uncommon (occurring in as many as $15 \%$ of all PBI cases), and include meningitis, ventriculitis and cerebral abscess due to contaminated foreign objects, skin, hair and bone fragments. Staphylococcus aureus is the most frequently reported infectious agent, although gram-negative bacteria may also be implicated. ${ }^{6}$ Prophylactic parenteral broad-spectrum antibiotics should be administered as soon as possible in all PBI cases. Based on this principle, we started intravenous amoxicillin-clavulanate, and no infectious complications were registered.

Cerebrospinal fluid (CSF) leaks may also develop in PBI patients due to possible dural tears; CSF leaks can present through the entry or exit sites of the penetrating object, as well as through the ear or nose when mastoid air cells or paranasal sinuses have been violated respectively. Temporary CSF diversion through a ventricular catheter or lumbar drain is generally performed when CSF leaks do not stop spontaneously. Surgical correction (either by direct closure of dural defects, or by using grafting materials) is recommended for refractory cases. ${ }^{8}$
Finally, $30 \%$ to $50 \%$ of PBI patients develop posttraumatic epilepsy, mainly because of cerebral scarring. In $\sim 10 \%$ of the cases, seizures will develop within the first 7 days after the trauma, and in $80 \%$, during the first 2 years. ${ }^{6}$ Aarabi et al. ${ }^{9}$ reported significant differences in late-onset epilepsy in PBI patients according to the admission GCS score. Since our patient was admitted with a GCS score of 15 , no antiseizure drugs were introduced.

\section{Conclusion}

Crossbow injuries to the skull are rare and usually have a fatal outcome. ${ }^{5}$ Our case report is unique, as the patient survived a total of three suicide attempts from a self-inflicted crossbow, one of which crossed both cerebral hemispheres. Furthermore, the patient was discharged three days after the trauma, with mild left hand apraxia and no other neurologic deficits. To the best of our knowledge, there are no other case reports describing simultaneously a good clinical outcome and rapid discharge after a bihemispheric PBI.

We also described our experience with the removal of the penetrating arrow in the $\mathrm{CT}$ suite, discussed its advantages, and reviewed some of the most frequent complications of PBI.

Our case report reinforces the need to individualize the management of each PBI patient to achieve the best possible outcome. Further research in trauma is needed, as PBI cases still represent a significant challenge to neurosurgeons worldwide.

\section{Conflict of Interests}

The authors have no conflict of interests to declare.

\section{References}

1 Suess O, Kombos T, Suess S, Stendel R, Silva CD, Brock M. SelfInflicted Intracranial Injury Caused by a Crossbow Arrow. Eur J Trauma 2002;28(05):310-313

2 Santiago LA, Oh BC, Dash PK, Holcomb JB, Wade CE. A clinical comparison of penetrating and blunt traumatic brain injuries. Brain Inj 2012;26(02):107-125

3 Kulwin CG, DeNardo A, Khairi S, Payner T. Neurosurgical Management of Self-Inflicted Cranial Crossbow Injury. World Neurosurg 2018;116:69-71

4 Jain D, Aggarwal G, Lubana P, Moses S. Penetrating craniofacial arrow injury. J Neurosci Rural Pract 2010;1(01):17-19

5 de Jongh K, Dohmen D, Salgado R, , et al. "William Tell” injury: MDCT of an arrow through the head. AJR Am J Roentgenol 2004; 182(06):1551-1553

6 Kazim SF, Shamim MS, Tahir MZ, Enam SA, Waheed S. Management of penetrating brain injury. J Emerg Trauma Shock 2011;4 (03):395-402

7 Ishigami D, Ota T. Traumatic Pseudoaneurysm of the Distal Anterior Cerebral Artery Following Penetrating Brain Injury Caused by a Crossbow Bolt: A Case Report. NMC Case Rep J 2017;5(01):21-26

8 Esposito DP, Walker JB. Contemporary Management of Penetrating Brain Injury. Neurosurg Q 2009;19(04):249-254

9 Aarabi B, Taghipour M, Haghnegahdar A, Farokhi M, Mobley L. Prognostic factors in the occurrence of posttraumatic epilepsy after penetrating head injury suffered during military service. Neurosurg Focus 2000;8(01):e1 